\title{
The ErbB4 Neuregulin Receptor Mediates Suppression of Oligodendrocyte Maturation
}

\author{
Caroline R. Sussman, ${ }^{1}$ Timothy Vartanian, ${ }^{3}$ and Robert H. Miller ${ }^{2}$ \\ Departments of ${ }^{1}$ Physiology and Biophysics and ${ }^{2}$ Neurosciences, Case Western Reserve University, Cleveland, Ohio 44106-4965, and ${ }^{3}$ Department of \\ Neurology, Beth Israel Deaconess Medical Center, Boston, Massachusetts 02115
}

\begin{abstract}
Neuregulin is required for proper oligodendrocyte development, but which receptors are involved and whether neuregulin promotes or inhibits maturation remain controversial. To assess the roles of the neuregulin receptor ErbB4 in oligodendrocyte development, we examined oligodendrocyte initiation and maturation in cultures derived from erbB4 knock-out mice and rat spinal cord in the presence of neutralizing erbB4 antibodies. No differences in the development of $\mathrm{O4}^{+}$oligodendrocytes were detected in the presence or absence of erbB4 signaling. All four epidermal growth factor receptor family members were detected in the ventral neural tube at approximately the time of initial oligodendrocyte development, consistent with redundancy in neuregulin receptor signaling at the onset of oligodendrocyte development. In contrast, greater numbers of differentiated (monoclonal antibody $01^{+}$) oligodendrocytes developed in neural tube explants from erbB4 ${ }^{-/-}$mice than either $e r b B 4^{+/+}$or $\mathrm{erbB}^{+/-}$littermates as well as in cultures treated with anti-erbB4. These data indicate that ErbB4 is not required for oligodendrocyte development and, in fact, inhibits oligodendrocyte lineage maturation. Together with previous studies, these data suggest a model in which early oligodendrocyte lineage development is regulated by promiscuous neuregulin receptor signaling, but subsequent lineage progression occurs through a balance of receptor-specific promotion or inhibition of maturation.
\end{abstract}

Key words: differentiation; neural tube; oligodendrocyte; receptor; growth factor; embryo; neuregulin; erbB4; spinal cord; CNS; immunohistochemistry; knock-out

\section{Introduction}

The neuregulin family of growth factors has profound effects on the development of oligodendrocytes, the myelinating cells of the CNS. Among them is the lack of $\mathrm{O}^{+}{ }^{+}$oligodendrocytes in the absence of neuregulin-1 in vitro (Vartanian et al., 1999). Neuregulin-1 knock-out mice die during midgestation before the first oligodendrocytes arise; however, oligodendrocyte development occurs in neural tube explants from midgestation wild-type embryos on a schedule similar to the schedule that occurs in vivo (Warf et al., 1991), allowing analysis of the effect of an absence of neuregulin. In contrast, the earliest committed oligodendrocytes fail to arise in parallel cultures from neuregulin-1 knock-out mice, and this effect can be rescued by addition of recombinant neuregulin to explant culture medium from embryonic day 10 (E10) onward. The loss of $\mathrm{O}^{+}$oligodendrocytes can be phenocopied by addition of a soluble neuregulin inhibitor to wild-type explant cultures, suggesting a direct effect of neuregulin on neural tube tissue.

Neuregulins have pleiotropic effects on oligodendrocyte de-

Received Nov. 19, 2004; revised May 3, 2005; accepted May 3, 2005.

This work was supported by National Institutes of Health Grants NS 30800 (R.H.M.) and NS 42317 (T.V.) and a Wadsworth Foundation Young Investigator grant (C.R.S.). We thank Dr. Greg Lemke for providing erbB4 knock-out mice, Dr. Martin Gassmann for advice on genotyping the mice, and Rae Wang for excellent technical support.

Correspondence should be addressed to Caroline R. Sussman, Department of Physiology and Biophysics, Case Western Reserve University, School of Medicine, Cleveland, OH 44106-4970. E-mail: caroline.sussman@case.edu. D0I:10.1523/JNEUROSCI.4748-04.2005

Copyright $\odot 2005$ Society for Neuroscience $\quad$ 0270-6474/05/255757-06\$15.00/0 velopment. Neuregulin increases cell numbers, survival, or proliferation (Vartanian et al., 1994; Canoll et al., 1996; Raabe et al., 1997; Cannella et al., 1998; Fernandez et al., 2000; Flores et al., 2000; Sussman et al., 2000; Colognato et al., 2002; Lai and Feng, 2004). Effects of neuregulin appear to depend on environmental influences. Several studies have demonstrated either no effect or a negative effect of neuregulin on oligodendrocyte cell numbers (Vartanian et al., 1994; Raabe et al., 1997; Canoll et al., 1999; Calaora et al., 2001), and these contrasting data may reflect the conditions under which the cells were grown. Neuregulins also influence the maturation of oligodendrocyte lineage cells, either promoting or inhibiting process formation and expression of mature oligodendrocyte markers (O1 and MBP) (Vartanian et al., 1994; Canoll et al., 1996, 1999; Raabe et al., 1997). Consistent with environmental influences on neuregulin responses, the differential effects of neuregulins may reflect interaction with other signaling systems such as the integrins because contact with laminin alters neuregulin signaling and effects on oligodendrocyte survival and differentiation (Colognato et al., 2002).

The synergistic interactions of neuregulin with other ligandreceptor systems are likely to result from activation of different signal transduction pathways. Neuregulin receptors activate multiple signaling cascades, and their signaling is altered depending on receptor composition (Carpenter, 2003). Neuregulins signal through homodimerized or heterodimerized receptors of the epidermal growth factor receptor (EGFR) family, EGFR, ErbB2, ErbB3, and ErbB4 (Yarden and Sliwkowski, 2001; Murphy et al., 
2002; Carpenter, 2003; Citri et al., 2003). Studies investigating ErbB2 and ErbB3 demonstrate that neither is required for oligodendrocyte progenitor development (Park et al., 2001; Stolt et al., 2002; Kim et al., 2003; Schmucker et al., 2003). Although ErbB2 appears important in the transition from progenitor to differentiated oligodendrocyte, ErbB3 is dispensable for oligodendrocyte maturation. Because ErbB2 requires a neuregulin-binding dimerization partner to exert its effects, these results imply that ErbB4 is involved in oligodendrocyte progenitor maturation.

\section{Materials and Methods}

Neural tube explant cultures. Embryos from erbB4 ${ }^{+/-}$mice (Gassmann et al., 1995) were removed at E9.5 (day of plug = day 0.5). The neural tube between the lateral ventricles and the posterior limb buds was removed in calcium- and magnesium-free MEM (Sigma, St. Louis, MO), sliced in cross sections to obtain approximately seven explants per embryo, and grown in Matrigel (BD Biosciences, Franklin Lakes, NJ) for the indicated time. Rat spinal cord cultures $(\mathrm{E} 14+7)$ were grown as described previously (Sussman et al., 2002) in the presence of $10 \mu \mathrm{g} / \mathrm{ml}$ anti-erbB4 (antibody 72; Neomarkers, Fremont, CA) or control IgG. Cell proliferation was assayed after a $15 \mathrm{~h}$ pulse of $10 \mu \mathrm{M}$ 5-bromo-2-deoxyuridine (BrdU) (Sigma). Cultures were grown in DMEM (Cellgro, Herndon, VA) supplemented with $1 \%$ FBS (HyClone, Logan, UT), 1\% ITS supplement (Sigma), and $10 \mathrm{ng} / \mathrm{ml}$ PDGF-AA (Sigma). Cells were maintained at $37^{\circ} \mathrm{C}\left(5 \% \mathrm{CO}_{2}\right.$ and $95 \%$ air $)$ in a humidified incubator.

Genotyping. Genomic DNA was extracted from embryos using the DNeasy kit (Qiagen, Hilden, Germany) according to the manufacturer's instructions. PCR was used to distinguish genotypes using the following primers: 5'-CTG CAC GAG ACT AGT GAG AC, 5'-TGT GCG CAG GAA CAG AGA AC, and 5'-CCG CAG GAA GGA GAG GTC. Primers, DNA, and Ex Taq (Takara, Fisher Scientific, Hampton, NH) were cycled on a DNA engine thermal cycler at $94^{\circ} \mathrm{C}$ for $2 \mathrm{~min}, 35$ times at $94^{\circ} \mathrm{C}$ for 1 min, $60^{\circ} \mathrm{C}$ for $1 \mathrm{~min}$, and $72^{\circ} \mathrm{C}$ for $1 \mathrm{~min}$, followed by a final extension at $72^{\circ} \mathrm{C}$ for $5 \mathrm{~min}$. This yielded bands of $155 \mathrm{~kb}$ (wild-type) and $320 \mathrm{~kb}$ (knock-out).

Immunocytochemistry. Explants were fixed in 4\% paraformaldehyde, labeled with monoclonal antibody (mAb) $\mathrm{O} 4$ or $\mathrm{O} 1$ hybridoma supernatant (1:5-1:2) overnight, and visualized with goat anti-mouse IgM conjugated to fluorescein isothiocyanate (MP Biomedicals, Irvine, CA). Cell cultures were labeled for $30 \mathrm{~min}$. Cell death was assessed with anticaspase 3 labeling and proliferation with anti-BrdU labeling as described previously (Sussman et al., 2002). Labeled cells were visualized and photographed under epifluorescence with a Zeiss (Thornwood, NY) microscope.

Reverse transcription-PCR. Neural tubes from mouse (CD-1; Harlan Sprague Dawley, Indianapolis, IN) or rat (Sprague Dawley; Zivic Laboratories, Pittsburgh, PA) embryos were dissected at indicated ages in calcium- and magnesium-free MEM (Sigma), meninges were removed, and dorsal ventral regions were separated along the sulcus limitans. mRNA was extracted from ventral neural tubes using Oligotex beads (Qiagen) according to the manufacturer's instructions, reversetranscribed using Superscript (Invitrogen, San Diego, CA), and used for PCR (as above). EGFR, erbB2 (Sundaresan et al., 1998), and erbB3 (Britsch et al., 2001) were amplified as described previously. ErbB4 was amplified as described above. The identities of the amplified products were confirmed by sequencing or restriction digest using four different restriction enzymes on each product.

Data analysis. Neural tube explants were cultured individually from each embryo. The data are expressed as mean \pm SEM. Statistical significance was assessed using a two-tailed $t$ test.

\section{Results}

Absence of erbB4 did not affect the development of $\mathrm{mAb}$ $\mathrm{O}^{+}$oligodendrocytes

Erbb4 knock-out mice die between 10 and $12 \mathrm{~d}$ of gestation before the first committed oligodendrocytes are easily detectable. In vitro, however, embryonic neural tubes grown in explant culture
A
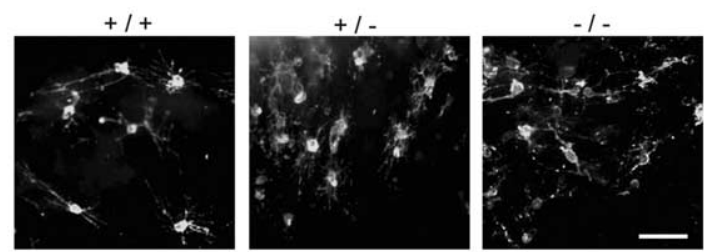

B
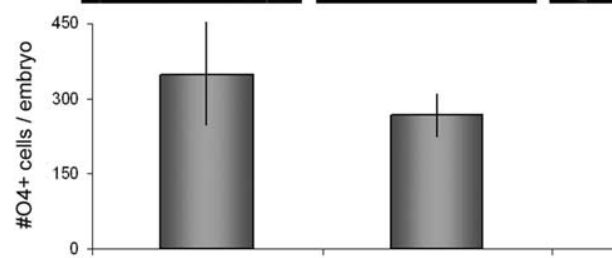

C

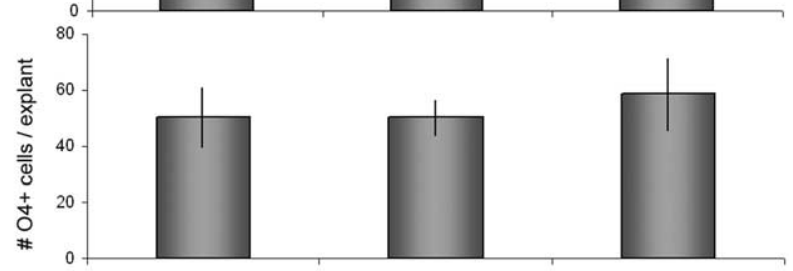

D

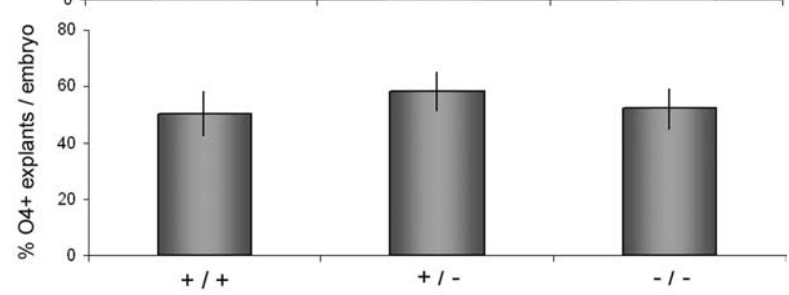

E
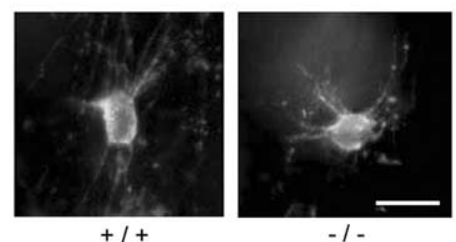

Figure 1. Oligodendrocyte development in erbB4 knock-out mice was indistinguishable from control or heterozygous littermates. $A$, Explants were grown for $9-10 \mathrm{~d}$, fixed, and labeled with $\mathrm{mAb} 04 . \boldsymbol{B}-\boldsymbol{D}$, The total number of $04^{+}$cells per embryo $(\boldsymbol{B})$ and per explant $(\boldsymbol{C})$ and the percentage of positive explants per embryo $(\boldsymbol{D})$ are shown as mean \pm SE. $\boldsymbol{E}$, Highermagnification view showing indistinguishable morphology ( $n=7-16$ embryos each). Scale bars: $A, 50 \mu \mathrm{m} ; \boldsymbol{E}, 20 \mu \mathrm{m}$.

develop $\mathrm{O}_{4}{ }^{+}$and $\mathrm{O}^{+}$oligodendrocytes at approximately the same time that these cells first appear in vivo (Warf et al., 1991). To determine whether the oligodendrocyte lineage developed normally in the absence of ErbB4 signaling, oligodendrocyte development was assessed in explant cultures derived from E9.5 erbB4 $4^{+/+}, e r b B 4^{+/-}$, and erbB $4^{-/-}$mice and E14 +7 rat cultures. Similar numbers of the same-size explants were generated from mice of each genotype, and neither the total number of $\mathrm{O}^{+}$cells nor their distribution among explants was significantly different after $9 \mathrm{~d}$ (Fig. 1). That is, both the number of $\mathrm{O}^{+}$cells per explant and the proportion of explants containing $\mathrm{O}_{4}^{+}$cells were similar. Likewise, in both control and anti-ErbB4 rat cultures, oligodendrocytes developed in 20-25 clusters containing similar numbers of $4^{+}$cells (control, $98 \pm 39$; anti-ErbB4, $116 \pm 36 ; n=3$ ). The overall morphologies of $\mathrm{O}_{4}{ }^{+}$cells were unaffected by anti-Erbb4 antibodies. There were no significant differences in either the number of primary processes per cell (control, $8.1 \pm 0.3$; antiErbB4, $7.9 \pm 0.3 ; p=0.6 ; n=20$ cells from three experiments) or the length of processes measured as cell diameters including processes (control, 71.6 $\pm 4 \mu \mathrm{m}$; anti-Erbb4, $70.4 \pm 4 \mu \mathrm{m} ; p>$ $0.8 ; n=20$ cells) (Fig. 2). 

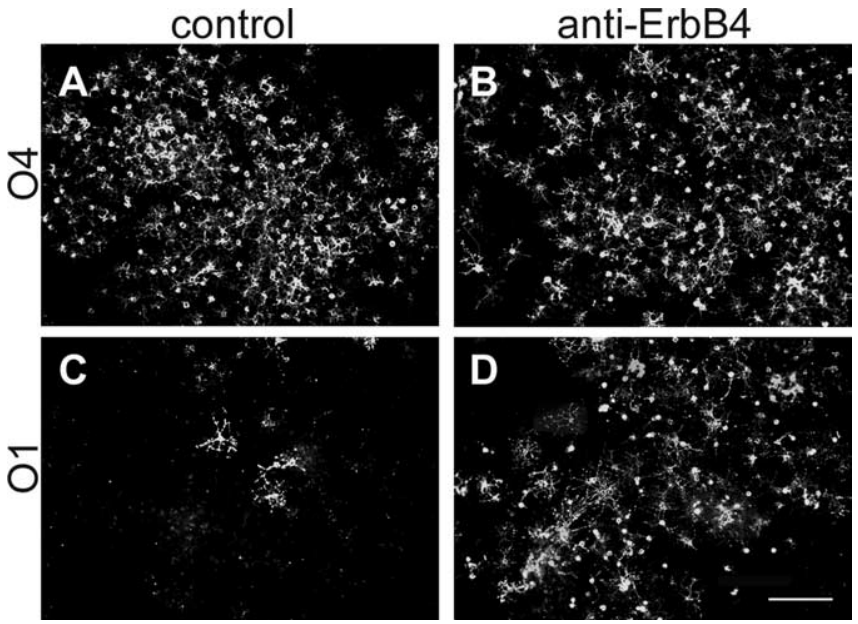

Figure 2. Greater numbers of $01^{+}$oligodendrocytes developed in the presence of antierbB4 antibody, whereas the number of $04^{+}$cells was not different. Rat cultures were grown in the presence of control $\lg (\boldsymbol{A}, \boldsymbol{C})$ or similar concentrations of anti-erbB4 $(\boldsymbol{B}, \boldsymbol{D})$ and labeled with $\mathrm{mAb} 04(\boldsymbol{A}, \boldsymbol{B})$ or $01(\boldsymbol{C}, \boldsymbol{D})$. Scale bar, $75 \mu \mathrm{m}$.

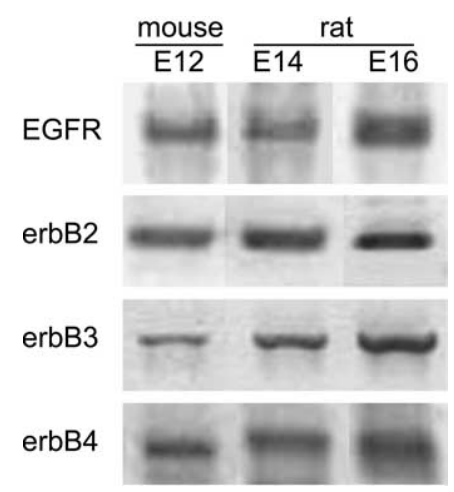

Figure 3. RT-PCR shows that all EGFR family members were expressed in the rodent ventral neural tube at the time of initial oligodendrocyte development.

\section{All EGFR family members were present during oligodendrocyte progenitor appearance}

The normal development of oligodendrocytes in the absence of ErbB4 signaling was surprising because neuregulin-1 is required for oligodendrocyte development (Vartanian et al., 1999), and this effect is independent of ErbB2 and ErbB3 (Park et al., 2001; Stolt et al., 2002; Schmucker et al., 2003). Together, these results suggest that there is functional redundancy among neuregulin receptors during early oligodendrocyte development. To assess this possibility, we examined the expression of all EGFR family members during spinal cord development.

Oligodendrocyte progenitors first arise in the ventral region of rodent embryonic neural tube at approximately E12 (mouse) or approximately E14 (rat). Reverse transcription (RT)-PCR of E12, E14, and E16 rodent ventral neural tube showed clear expression of all four EGFR family members (Fig. 3). Identities of PCR products were confirmed by sequencing or by restriction digests with four different enzymes.

\footnotetext{
Absence of erbB4 modified oligodendrocyte

lineage maturation

To assess the effect of ErbB4 on maturation of oligodendrocyte progenitors, the appearance of mature $\left(\mathrm{O}^{+}\right)$oligodendrocytes
}

A
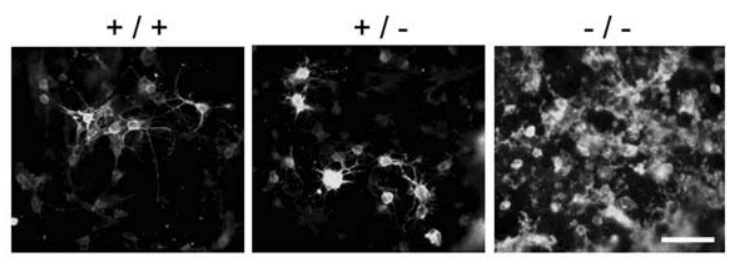

\section{B \\ C}
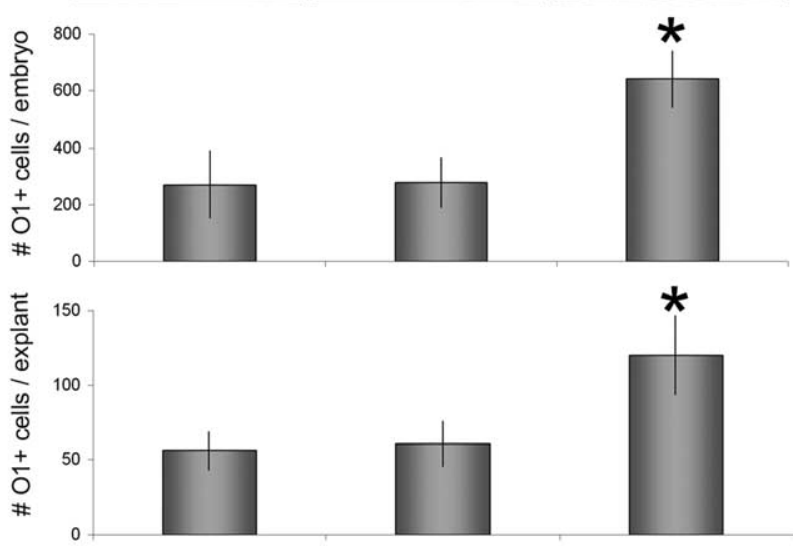

$\mathrm{D}$

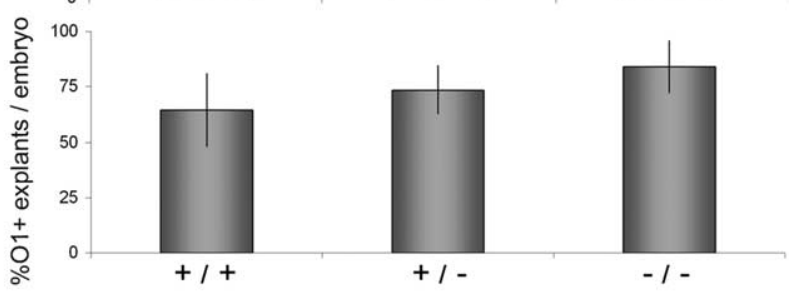

$E$
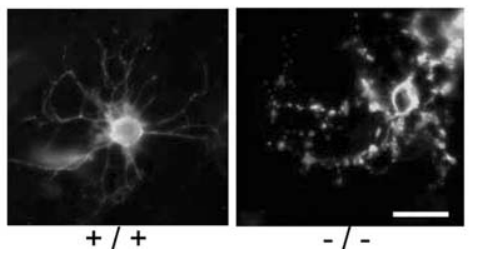

Figure 4. Homozygous erbB4 knock-outs produced more $01^{+}$oligodendrocytes. $\boldsymbol{A}$, Explants were grown for $12-14 d$, fixed, and labeled with $m A b 01 . B-D$, The total number of $01^{+}$ cells per embryo $(\boldsymbol{B})$ and per explant $(\boldsymbol{C})$ and the percentage of positive explants per embryo (D) are shown as mean $\pm S E$. $E$, Higher-magnification view showing characteristic disrupted mem-

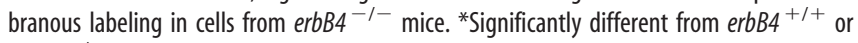
erbB4 ${ }^{+-}$by $t$ test $(t<0.05 ; n=3-7$ embryos). Scale bars: $A, 50 \mu \mathrm{m} ; \boldsymbol{E}, 20 \mu \mathrm{m}$.

was examined from erbB4 knock-out mice. The first $\mathrm{O}^{+}{ }^{+}$cells appeared in E9.5-derived neural tube explants from mice of all erbB4 genotypes between 10 and $12 \mathrm{~d}$ in vitro (data not shown), suggesting that the overall timing of oligodendrocyte maturation was not affected by the absence of ErbB signaling. Quantitative analyses, however, revealed a significant difference in the number of mature oligodendrocytes that developed in the absence of erbB4 (Fig. 4A,B). After 12-14 d in vitro, the number of $\mathrm{O}^{+}$ oligodendrocytes was dramatically higher in the erbB4 $4^{-1-}$ derived explants $(642 \pm 101)$ compared with control animals $(270 \pm 119)$ or heterozygous animals $(277 \pm 89)$. This increase in number reflected local cell maturation. For example, the number of $\mathrm{O}^{+}$cells per explant increased significantly, although the proportion of $\mathrm{O}^{+}$explants was unchanged, suggesting that the rostrocaudal distribution of oligodendrocyte progenitors in the developing neural tube was not different (Fig. 4C,D). Comparable results were obtained in rat cultures. The number of $\mathrm{O}^{+}$ cells per cluster increased from $23 \pm 17$ in controls to $108 \pm 31$ in anti-ErbB4-treated cultures $(n=3)$. 
BrdU and caspase 3 labeling indicated that neither an increase in proliferation nor a decrease in cell death explained the increase in $\mathrm{O}^{+}$cell number. Inhibition of ErbB4 signaling did not alter BrdU or caspase 3 labeling of $\mathrm{O}^{+}$cells, whereas the proportion of BrdU-labeled $\mathrm{O}^{+}{ }^{+}$cells decreased by almost 50\% (14 \pm 3 to $8 \pm 3 \% ; p=0.01 ; n=3)$, and that of caspase 3-labeled $\mathrm{O} 1{ }^{+}$cells increased by $35 \%(19 \pm 4$ to $54 \pm 14 \% ; p=0.0006 ; n=3)$ in the presence of anti-ErbB4. In addition to affecting cell number, the absence of ErbB4 signaling clearly altered the morphology of $\mathrm{O}^{+}$cells (Fig. 4E). Together, these data indicate a critical role of ErbB4 in normal oligodendrocyte maturation.

\section{Discussion}

ErbB4 was not required for development of $\mathrm{O} 4^{+}$ oligodendrocyte lineage cells, suggesting involvement of promiscuous neuregulin and receptor signaling

The similar distribution of $\mathrm{O}^{+}$cells in $\mathrm{E} 9.5 \mathrm{erbB}^{+/+}$,

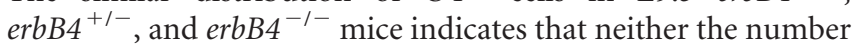
of initial progenitor cells nor their subsequent proliferation was altered in the absence of ErbB4 signaling. The fact that both the number of $\mathrm{O}_{4}^{+}$cells per explant and the proportion of explants that contained $\mathrm{O}_{4}^{+}$cells were similar among genotypes implies that the founder cells of the oligodendrocyte lineage are distributed similarly along the rostrocaudal axis in the neural tubes of each genotype. Rat cultures in the presence and absence of antiErbB4 supported these observations and directly demonstrated the lack of an effect on $\mathrm{O}_{4}{ }^{+}$cell proliferation and death. These data are in contrast to the results of similar experiments on neuregulin-1-null animals in which the appearance of $\mathrm{O} 4^{+}$cells was dramatically inhibited (Vartanian et al., 1999), suggesting that this effect does not require ErbB4 signaling.

Neuregulin has been proposed to regulate the morphology of maturing oligodendrocytes (Vartanian et al., 1994; Canoll et al., 1996; Raabe et al., 1997; Colognato et al., 2002); however, our data indicated no obvious differences in the number or length of cell processes or in the size of the cell bodies associated with the erbB4 genotype. The data therefore suggested that ErbB4 was expendable for normal neural tube oligodendrocyte development in terms of commitment to the lineage, survival, proliferation, and morphological development.

The finding that $\mathrm{O}_{4}{ }^{+}$oligodendrocytes developed in the absence of ErbB4 was surprising because neuregulin is critical for their development (Vartanian et al., 1999), and yet oligodendrocyte progenitors arise normally in the absence of the other neuregulin receptors, ErbB2 and ErbB3 (Park et al., 2001; Stolt et al., 2002; Kim et al., 2003; Schmucker et al., 2003). These observations suggest that there is redundancy among neuregulin receptors during early stages of the oligodendrocyte lineage, a possibility supported by the data presented here showing expression of all EGFR family members at the time and place of oligodendrocyte progenitor appearance in the spinal cord. Thus, expression of EGFR family members is consistent with a model of promiscuous neuregulin receptor signaling regulating early oligodendrocyte lineage development.

\section{Absence of erbB4 modified oligodendrocyte lineage maturation}

Most studies of neuregulin and receptor effects on oligodendrocytes do not distinguish between early and later effects on the lineage, although a requirement for ErbB2 specifically in oligodendrocyte maturation has been demonstrated (Park et al., 2001; Kim et al., 2003). Similarly, our data indicated a role for ErbB4 specifically in oligodendrocyte maturation; however, although
ErbB2 is required for maturation, absence of ErbB4 promoted maturation, implying that ErbB4 inhibits oligodendrocyte maturation.

Several environmental factors are known modulators of oligodendrocyte maturation and myelination. For example, galactolipids are influential in oligodendrocyte development and maturation (Bansal and Pfeiffer, 1989; Marcus et al., 2000). Similarly, fibroblast growth factor-2 potently inhibits oligodendrocyte maturation by stimulating proliferation and preventing terminal differentiation (Bansal, 2002). Whether there is any relationship between ErbB4 activity and the effects on oligodendrocyte maturation by these factors is unknown.

There are several possible mechanisms that might account for the increase in $\mathrm{O}^{+}$cells in erbB4 ${ }^{-1-}$ neural tube explants. Enhanced progenitor proliferation would lead to elevated numbers of $\mathrm{O}^{+}$cells. This is unlikely, however, because there was not a dramatic increase in $\mathrm{O}_{4}{ }^{+}$cells, cell proliferation is relatively low in $\mathrm{O}^{+}$cells, and the BrdU incorporation studies did not demonstrate a positive effect of anti-ErbB4 on the proliferation of either cell type. During transition from progenitors to differentiated oligodendrocytes, oligodendrocyte progenitors are particularly susceptible to cell death (Barres et al., 1992). A reduction in cell death would result in increased numbers of $\mathrm{O}^{+}$cells in the erbB4-null animals; however, this also seems unlikely because significant cell death of oligodendrocytes was not seen in wildtype- or heterozygous-derived explants or in control rat cultures. Furthermore, in erbB4 $4^{-1-}$ animals, many of the $\mathrm{O} 1^{+}$cells had an altered morphology (Fig. 4) characteristic of dying cells (Trapp et al., 1997), suggesting that, instead of decreased cell death, there was increased cell death in the absence of erbB4. Consistent with this hypothesis, cell death of $\mathrm{O}^{+}$cells increased in the antiErbB4-treated cultures $>30 \%$ compared with controls. This increased cell death may result from competition among the additional cells for survival factors that become limiting as a result of increased cell number. Although the effect may not be completely autonomous to the oligodendrocyte lineage, a direct effect is likely because oligodendrocyte progenitors express all three ErbB receptors (Canoll et al., 1996; Raabe et al., 1997; Flores et al., 2000; Park et al., 2001).

The observation that ErbB4 and ErbB2 deletion results in opposite effects on oligodendrocyte development suggests divergent downstream signaling from these two receptors. In other cell types, evidence indicates that signaling downstream of ErbB2 differs from that of ErbB4, and even signaling of EbB4 homodimers differs from that of ErbB4-ErbB2 heterodimers (Carpenter, 2003; Citri et al., 2003). Arrays of downstream signaling cascades are activated by both ErbB2 and ErbB4, including phosphatidylinositol-3-kinase/Akt, Janus kinase/signal transducer and activator of transcription, and Ras/extracellular signalregulated kinase. The specific signaling events induced vary depending on dimer composition, a potentially highly variable parameter in the developing CNS. All EGFR members are present in the developing CNS, including the regions that generate oligodendrocytes (Fig. 3) and within cells spanning the oligodendrocyte lineage (Canoll et al., 1996; Pinkas-Kramarski et al., 1997; Raabe et al., 1997, 2004; Vartanian et al., 1997; Deadwyler et al., 2000; Flores et al., 2000; Kornblum et al., 2000; Calaora et al., 2001; Park et al., 2001; Schmucker et al., 2003). ErbB2 acts only as a heterodimer and is the preferred dimerization partner for all EGFR family members, although dimer composition is ultimately a function of both affinity and levels of expression of receptor monomers (Tzahar et al., 1996; Graus-Porta et al., 
1997). Thus, the potential for differential signaling in the oligodendrocyte lineage is extensive.

The differential responses of the oligodendrocyte lineage to selective deletion of ErbB receptors provide a potential explanation for the diversity of effects seen in response to neuregulin in vitro. For example, exposure to neuregulin results in diminished process formation and expression of mature markers (Canoll et al., 1996, 1999; Colognato et al., 2002). In contrast, other studies have shown that neuregulin increases oligodendrocyte maturation as assayed by process formation (Vartanian et al., 1994; Raabe et al., 1997). These apparently contradictory results may be reconciled if the conditions under which the cells are grown influence the expression of distinct ErbB receptors. Relatively high expression of ErbB2 and low expression of ErbB4 would tend to induce differentiation in response to neuregulin, whereas low expression of ErbB2 and high expression of ErbB4 would result in inhibition of differentiation. This model is consistent with the observation that neuregulin and ErbB4 expression decreases with time in culture and maturation of oligodendrocyte progenitors, whereas ErbB2 and ErbB3 levels rise or remain constant (Canoll et al., 1996; Calaora et al., 2001). In addition, this model could explain the variable effects of neuregulin depending on the availability of laminin-2 (Colognato et al., 2002).

In summary, our results demonstrate an inhibitory effect of ErbB4 on oligodendrocyte maturation and may explain the numerous dedifferentiating effects of neuregulin that have been reported. Combined with the results of others, our data suggest a model in which neuregulin has pleiotropic effects on oligodendrocyte lineage development, depending on the composition of its receptors. Neuregulin may act via all receptor dimer combinations to promote oligodendrocyte lineage commitment, survival, and proliferation. Maturation, however, may occur only through ErbB2-containing dimers, whereas it may be suppressed by ErbB4-containing dimers. Downregulation of ErbB4 would then be required to allow maturation. Although this is the most straightforward model that accounts for both maturationpromoting and -inhibiting effects of neuregulin, additional complexity, including environmental factors and the involvement of nonoligodendrocyte lineage cells, may contribute to cellular responses.

\section{References}

Bansal R (2002) Fibroblast growth factors and their receptors in oligodendrocyte development: implications for demyelination and remyelination. Dev Neurosci 24:35-46.

Bansal R, Pfeiffer SE (1989) Reversible inhibition of oligodendrocyte progenitor differentiation by a monoclonal antibody against surface galactolipids. Proc Natl Acad Sci USA 86:6181-6185.

Barres BA, Hart IK, Coles HS, Burne JF, Voyvodic JT, Richardson WD, Raff MC (1992) Cell death and control of cell survival in the oligodendrocyte lineage. Cell 70:31-46.

Britsch S, Goerich DE, Riethmacher D, Peirano RI, Rossner M, Nave KA, Birchmeier C, Wegner M (2001) The transcription factor Sox10 is a key regulator of peripheral glial development. Genes Dev 15:66-78.

Calaora V, Rogister B, Bismuth K, Murray K, Brandt H, Leprince P, Marchionni M, Dubois-Dalcq M (2001) Neuregulin signaling regulates neural precursor growth and the generation of oligodendrocytes in vitro. J Neurosci 21:4740-4751.

Cannella B, Hoban CJ, Gao YL, Garcia-Arenas R, Lawson D, Marchionni M, Gwynne D, Raine CS (1998) The neuregulin, glial growth factor 2, diminishes autoimmune demyelination and enhances remyelination in a chronic relapsing model for multiple sclerosis. Proc Natl Acad Sci USA 95:10100-10105.

Canoll PD, Musacchio JM, Hardy R, Reynolds R, Marchionni MA, Salzer JL (1996) GGF/neuregulin is a neuronal signal that promotes the prolifera- tion and survival and inhibits the differentiation of oligodendrocyte progenitors. Neuron 17:229-243.

Canoll PD, Kraemer R, Teng KK, Marchionni MA, Salzer JL (1999) GGF/ neuregulin induces a phenotypic reversion of oligodendrocytes. Mol Cell Neurosci 13:79-94.

Carpenter G (2003) ErbB-4: mechanism of action and biology. Exp Cell Res 284:66-77.

Citri A, Skaria KB, Yarden Y (2003) The deaf and the dumb: the biology of ErbB-2 and ErbB-3. Exp Cell Res 284:54-65.

Colognato H, Baron W, Avellana-Adalid V, Relvas JB, Baron-Van Evercooren A, Georges-Labouesse E, ffrench-Constant C (2002) CNS integrins switch growth factor signalling to promote target-dependent survival. Nat Cell Biol 4:833-841.

Deadwyler GD, Pouly S, Antel JP, Devries GH (2000) Neuregulins and erbB receptor expression in adult human oligodendrocytes. Glia 32:304-312.

Fernandez PA, Tang DG, Cheng L, Prochiantz A, Mudge AW, Raff MC (2000) Evidence that axon-derived neuregulin promotes oligodendrocyte survival in the developing rat optic nerve. Neuron 28:81-90.

Flores AI, Mallon BS, Matsui T, Ogawa W, Rosenzweig A, Okamoto T, Macklin WB (2000) Akt-mediated survival of oligodendrocytes induced by neuregulins. J Neurosci 20:7622-7630.

Gassmann M, Casagranda F, Orioli D, Simon H, Lai C, Klein R, Lemke G (1995) Aberrant neural and cardiac development in mice lacking the ErbB4 neuregulin receptor. Nature 378:390-394.

Graus-Porta D, Beerli RR, Daly JM, Hynes NE (1997) ErbB-2, the preferred heterodimerization partner of all ErbB receptors, is a mediator of lateral signaling. EMBO J 16:1647-1655.

Kim JY, Sun Q, Oglesbee M, Yoon SO (2003) The role of ErbB2 signaling in the onset of terminal differentiation of oligodendrocytes in vivo. J Neurosci 23:5561-5571.

Kornblum HI, Yanni DS, Easterday MC, Seroogy KB (2000) Expression of the EGF receptor family members ErbB2, ErbB3, and ErbB4 in germinal zones of the developing brain and in neurosphere cultures containing CNS stem cells. Dev Neurosci 22:16-24.

Lai C, Feng L (2004) Implication of gamma-secretase in neuregulininduced maturation of oligodendrocytes. Biochem Biophys Res Commun 314:535-542.

Marcus J, Dupree JL, Popko B (2000) Effects of galactolipid elimination on oligodendrocyte development and myelination. Glia 30:319-328.

Murphy S, Krainock R, Tham M (2002) Neuregulin signaling via erbB receptor assemblies in the nervous system. Mol Neurobiol 25:67-77.

Park SK, Miller R, Krane I, Vartanian T (2001) The erbB2 gene is required for the development of terminally differentiated spinal cord oligodendrocytes. J Cell Biol 154:1245-1258.

Pinkas-Kramarski R, Eilam R, Alroy I, Levkowitz G, Lonai P, Yarden Y (1997) Differential expression of NDF/neuregulin receptors ErbB-3 and ErbB-4 and involvement in inhibition of neuronal differentiation. Oncogene 15:2803-2815.

Raabe TD, Suy S, Welcher A, DeVries GH (1997) Effect of neu differentiation factor isoforms on neonatal oligodendrocyte function. J Neurosci Res 50:755-768.

Raabe TD, Deadwyler G, Varga JW, Devries GH (2004) Localization of neuregulin isoforms and erbB receptors in myelinating glial cells. Glia 45:197-207.

Schmucker J, Ader M, Brockschnieder D, Brodarac A, Bartsch U, Riethmacher D (2003) erbB3 is dispensable for oligodendrocyte development in vitro and in vivo. Glia 44:67-75.

Stolt CC, Rehberg S, Ader M, Lommes P, Riethmacher D, Schachner M, Bartsch U, Wegner M (2002) Terminal differentiation of myelinforming oligodendrocytes depends on the transcription factor Sox 10. Genes Dev 16:165-170.

Sundaresan S, Roberts PE, King KL, Sliwkowski MX, Mather JP (1998) Biological response to ErbB ligands in nontransformed cell lines correlates with a specific pattern of receptor expression. Endocrinology 139:4756-4764.

Sussman CR, Dyer KL, Marchionni M, Miller RH (2000) Local control of oligodendrocyte development in isolated dorsal mouse spinal cord. J Neurosci Res 59:413-420.

Sussman CR, Davies JE, Miller RH (2002) Extracellular and intracellular regulation of oligodendrocyte development: roles of Sonic hedgehog and expression of E proteins. Glia 40:55-64.

Trapp BD, Nishiyama A, Cheng D, Macklin W (1997) Differentiation and 
death of premyelinating oligodendrocytes in developing rodent brain. J Cell Biol 137:459-468.

Tzahar E, Waterman H, Chen X, Levkowitz G, Karunagaran D, Lavi S, Ratzkin BJ, Yarden Y (1996) A hierarchical network of interreceptor interactions determines signal transduction by Neu differentiation factor/neuregulin and epidermal growth factor. Mol Cell Biol 16:5276-5287.

Vartanian T, Corfas G, Li Y, Fischbach GD, Stefansson K (1994) A role for the acetylcholine receptor-inducing protein ARIA in oligodendrocyte development. Proc Natl Acad Sci USA 91:11626-11630.

Vartanian T, Goodearl A, Viehover A, Fischbach G (1997) Axonal neuregu- lin signals cells of the oligodendrocyte lineage through activation of HER 4 and Schwann cells through HER2 and HER3. J Cell Biol 137:211-220.

Vartanian T, Fischbach G, Miller R (1999) Failure of spinal cord oligodendrocyte development in mice lacking neuregulin. Proc Natl Acad Sci USA 96:731-735.

Warf BC, Fok-Seang J, Miller RH (1991) Evidence for the ventral origin of oligodendrocyte precursors in the rat spinal cord. J Neurosci 11:2477-2488.

Yarden Y, Sliwkowski MX (2001) Untangling the ErbB signalling network. Nat Rev Mol Cell Biol 2:127-137. 